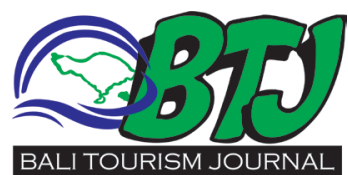

\title{
Historical trip to puncak Penulisan temple, a journey to discover ancient civilization of Bali Kuna Empire
}

\author{
I Gede Mas Suputra ${ }^{1}$
}

\section{ABSTRACT}

Beyond thick fog and ensnaring freeze of Penulisan hill, there is situated an ancient history. A temple that endured since far before the ruling of Bedahulu Dynasty dated back in the eighth century. The old site acts as a religious center, known by local as Puncak Penulisan Temple. It is located on the highest spot of Bangli regency. Puncak Penulisan temple is a temple complex, in a site resembles a seven level terraces pyramid. In ancient Balinese Kingdom period, between $882-1436 A D$, the community sanctified several temples, including Puncak Penulisan temple as a place to worship the spirit of ancestor as well as their ruler. Discovered artifacts from this ancient site encompass varies type of megalithic artifacts such as a stone carved with moon and sun image, a statue of Brahma, three pairs statues, two Lingga-Yoni as a symbol of Lord Shiva, Ganesha figure, and several mini rock shrine to worship the holy spirit. unlike other regions in Bali, in Puncak Penulisan temple, the ritual is led by a priest called Jero Kubayan. Furthermore, in every ceremony that takes place in the temple, is taking care by a group of people called Gebog domas. A group of people consists of 200 family heads from Sukawana, Kintamani, Selulung, and Bantang regions, bringing a total of 800 people. Gebog Domas played an essential role as a symbol of unity between villages as well as to strengthen the brotherhood.
'Sanggar Seni Madwe Karang mas.suputra@gmail.com

Editor:

Ida Bagus Ngurah Tri Pramana

Received: 2019-02-22 Accepted: 2019-03-01 Published: 2019-04-05

Keyword: Puncak Penulisan Temple, Sukawana, Ancient civilization, Artifact

Cite This Article: Suputra, I.G.M. Historical trip to puncak Penulisan temple, a journey to discover ancient civilization of Bali Kuna Empire. Bali Tourism Journal (BTJ)2019, 3 (1): 5-9

\section{INTRODUCTION}

Beyond thick fog and ensnaring freeze of Penulisan hill, there is situated an ancient history. A temple that endured since far before the ruling of Bedahulu Dynasty dated back in the eighth century. The old site acts as a religious center, known by local as Puncak Penulisan Temple. It is located on the highest spot of Bangli regency. Here, a visitor could learn multiple things in regards to ancient Balinese civilization, as well as enjoying its breathtaking landscape of Batur caldera.

Locals may refer Puncak penulisan temple by a different name. Some called it Tegeh Koripan temple due to folktale which mentioned the site as a spot for the ruler to meditate. Also, many often mentioned it as Pamojan temple or in the local tongue means King's arrow. This center of Hindus' activity is one of the most ancient shrines in Bali. Its grand design reflected Bali Mula and Bali Aga architecture due to the absence of Meru and gedong. Those two buildings are typical to be found in temple with Javanese influence after the Majapahit empire conquered Bali in the fourteenth century.

To visit Puncak Penulisan temple, it approximately takes two hours by vehicle from Denpasar city. From the capital city of Bali, It could be reached by using north routes through Petang Bangkung great bridge route or through Payangan route. Meanwhile, to reach the location from Kintamani, it only takes 30 minutes by vehicle. The site is located in Puncak penulisan hill in Sukawana Village, Bangli, 1745 meters above sea level. The climate around the area range from $14-27$ degree Celsius, with occasional fog, occurs after 1 pm. ${ }^{2}$

\section{THE TEMPLE'S ARCHITECTURE}

If it is closely observed, Puncak Penulisan temple is a temple complex comprises of five temples on the third, fourth, sixth, and seventh levels. The site resembles a pyramid with seven level terraces connecting with stairs. The shape of the pyramid in megalithic society represented a mountain, the holiest place to connect with the supreme being. Meanwhile, seven-level terraces, based on Hindus' teaching, is a symbol of Sapta Loka or seven realms in-universe. Here, most of the temples built facing south, except the main temple which is facing west. ${ }^{3}$

The first and second level, act as a rest area, including vehicle park. The first temple can be found on the swahloka or the third level. There are two temples namely Dana Temple where the local pray to the shrine of Ratu Ngurah kubayan as well as Ratu Bujangga, and Taman dana temple. One level above, on the eastern part of Maya Loka, there is a temple of Ratu Penyarikan, moreover, on the western part, a particular temple was built for 


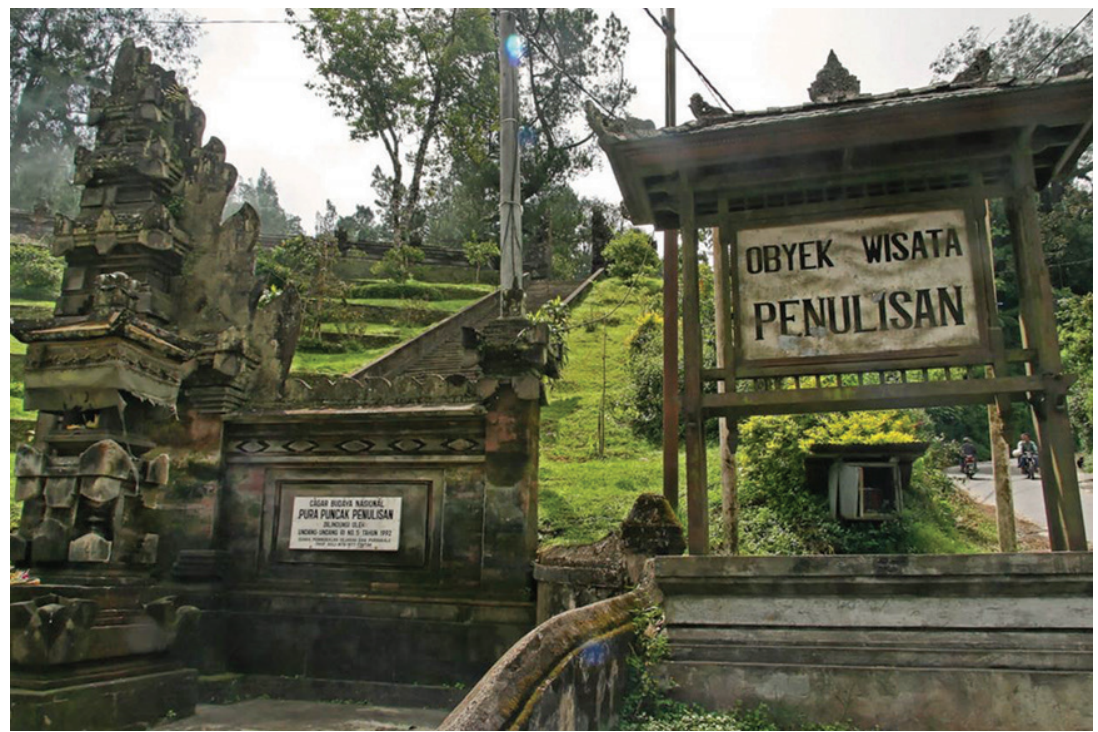

Figure 1. Front Gate of Puncak Penulisan Temple ${ }^{1}$

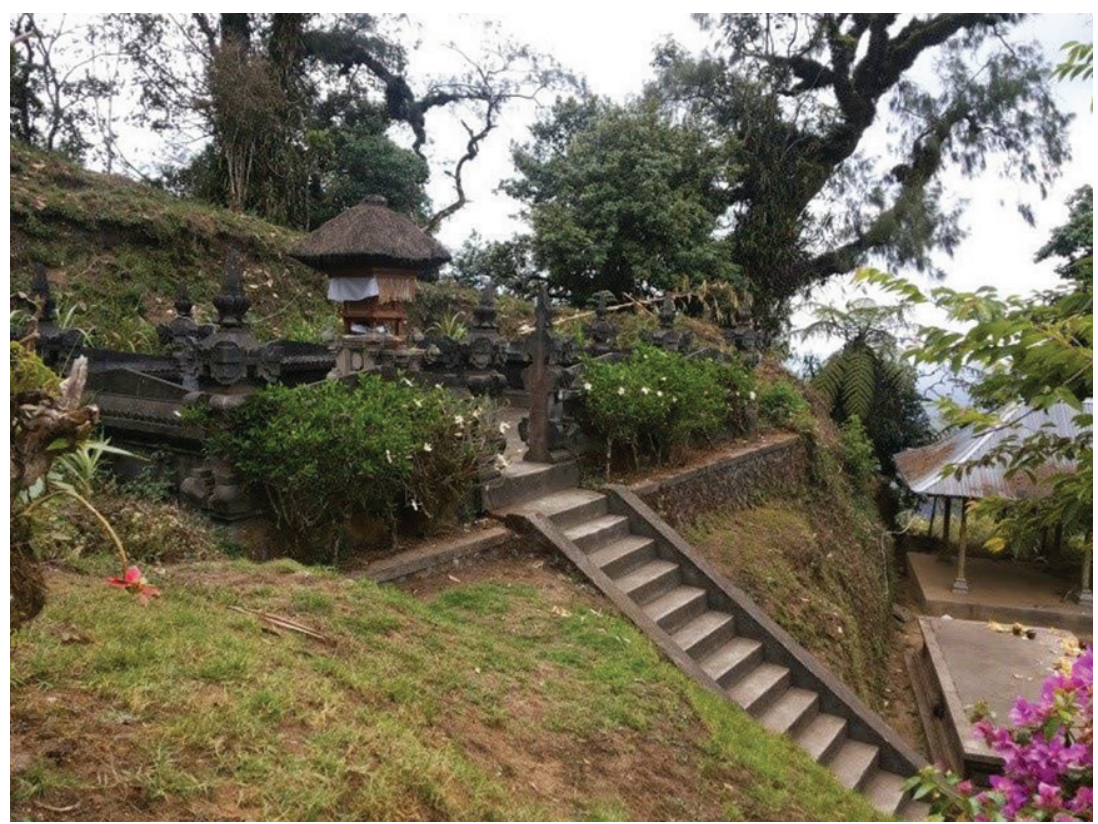

Figure 2 The site resembles a pyramid with seven level terraces connecting with stairs ${ }^{1}$

Bujangga clan.

Next, a temple named Daha Tua Temple can be found on level six or Tapa Loka. And on the highest section, Sunya Loka where the Tegeh koripan temple located. In this peak temple area, dozens of artifacts, mostly stone figures are displayed in Gedong. There is also an altar for pray, offering altar, and open chamber to display the old remnants. ${ }^{4}$

There is no written text, nor ancient inscription discussed the date when it was built. Nevertheless, scholar estimated the age of the megalithic temple according to related scripts that mentioned the temple existence. Until these days, it is believed the temple was built in the Bronze age, dated back in $300 \mathrm{AD} .5$

On Inscription of Sukawana label A-1 dated 804 Saka (882 AD), states that in Bukit Cintamani (now Kintamani area) there was a sacred spot. The inscription refers to the spot as Ulan. The king at that time, who was unnamed on the script, treated the place with special attention. He instructed his Senapati Danda (war chief) which was held by Kumpi Marodaya, assisted by monk Siwakangcita, Siwanirmmala, and Siwaprajna to rebuild the shrine. Thus it could be acted as a resting area for traveler or locals who often passed the area for working in their field. ${ }^{6}$

In one of DR. R Goris textbook, He discussed the condition of temples in Bali, and Puncak Penulisan Temple is one of the temples he mentioned. The text described an ancient Balinese Kingdom (Bali Kuna) with its capital city located at Bedulu, Pejeng. The community sanctified several temples, such as the Penataran Temple, at Pejeng, Gianyar, as the temple of origin in Bali. As a sea temple, it might be Puser Tasik Temple in Pejeng, whereas the temple to worship the ancestor spirit is Puncak Penulisan Temple, in Kintamani, Bangli. It is believed that the societies who lived in Bali Aga village nearby often prayed at the temple as well. Instead of only treated as a temple for ancestors, locals also praise their ruler at the temple. This claim is evidenced by the discovery of embodiment statues of the previous rulers, such as the figure of Bhatari Mandul which was believed as the embodiment of King Anak Wungsu's queen, who ruled in 1049-1077 AD.

\section{ARTIFACTS OF THE TEMPLE}

Discovered artifacts from this ancient site are neatly arranged in the main temple area. The types of megalithic artifacts such as a stone carved with moon and sun image, a statue of Brahma, three pairs statues, two Lingga-Yoni as a symbol of Lord Shiva, Ganesha figure, and several mini rock shrine to worship the holy spirit. There are hundreds of Lingga but not in pairs, with various forms were kept around the site. Some are intact, and some crumbled.

Research by Dr. WF Sturterheim concluded the ancient relics in the Pucak Penulisan temple originated from ancient Balinese kingdom. The conclusion was taken based on his finding of several inscriptions that described the past life of the society. The findings, for instance, are inscription with year 999 Saka (1077 AD) and 1352 Saka (1436 AD), A male-female figure with text carved behind it that 


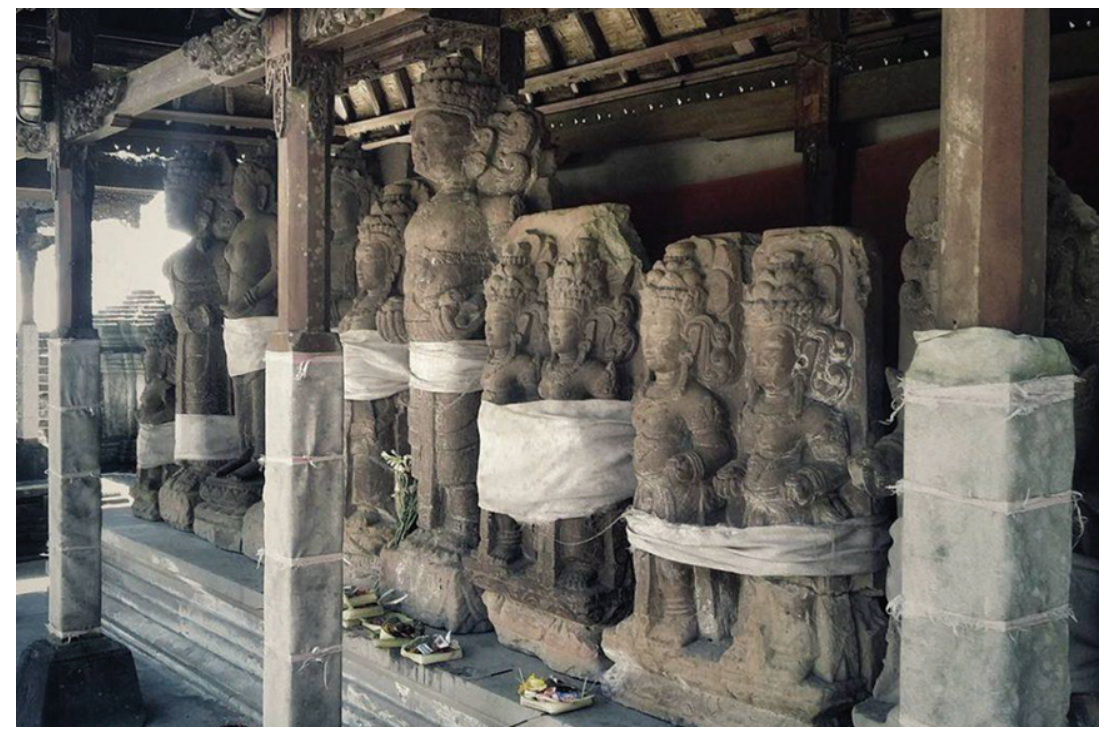

Figure 3. Discovered artifacts from this ancient site are neatly arranged in the main temple area. ${ }^{8}$

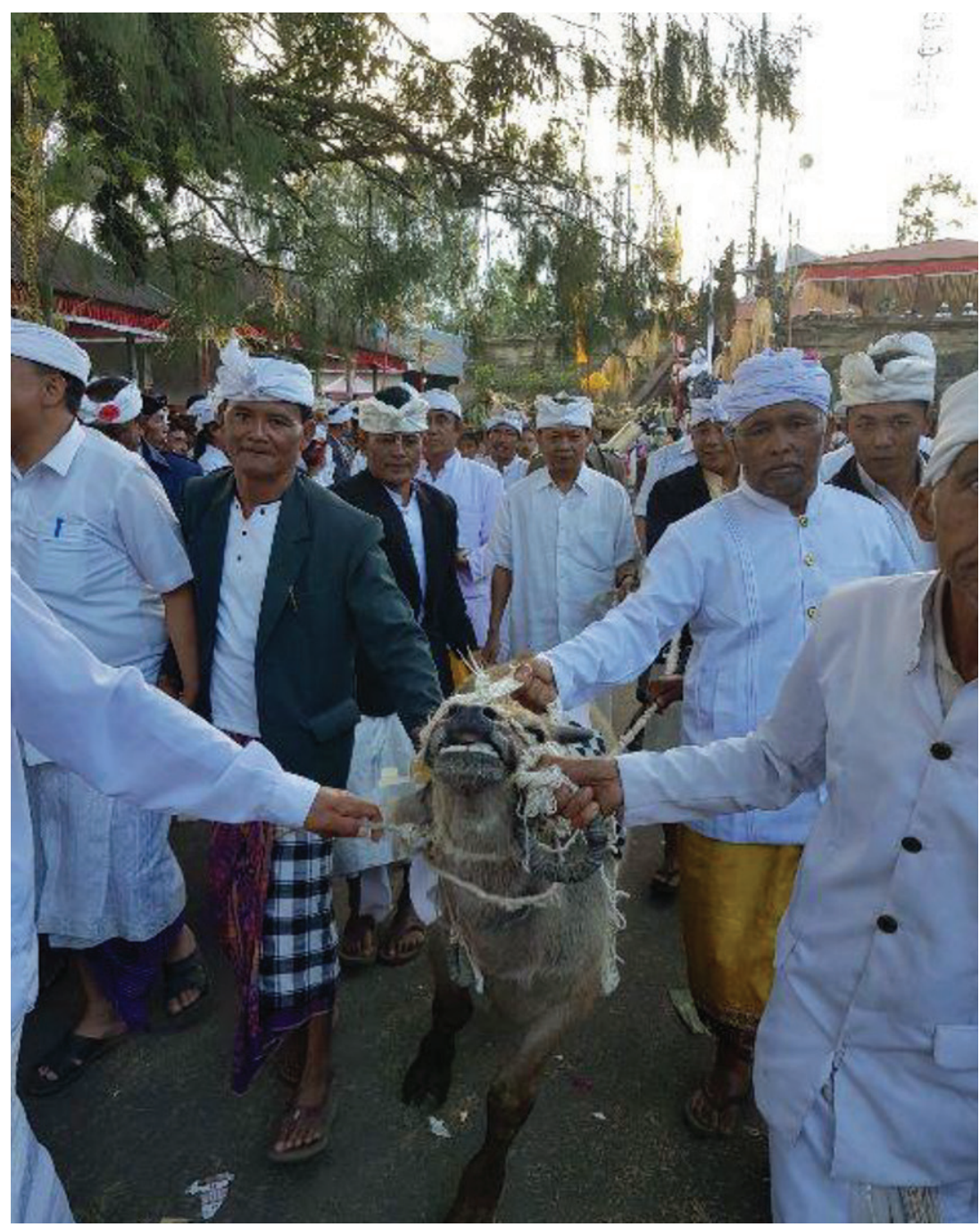

Figure 4. Every full moon on the fourth month in Balinese calendar, a deer and buffalo would be sacrificed ${ }^{12}$ explained the statue as an embodiment of King Udayana Warmadewa and his queen Gunapriya darmapatni. The king ruled the kingdom in Bali around 911-933 Saka. Then a standing female statue called the Batari Mandul, which is believed as the embodiment of the Empress of the King Anak wungsu who did not have any children.

Another research conducted by Team of researcher from udayana university in 1922 found a pair of sculptures, height $92 \mathrm{~cm}$, wearing a crown of karanda makuta and twisted hair earrings. At its base, there is an inscription year of 933 Saka (1026 AD), carved by Mpu Bga Anatah on the day of Wijaya Manggala. Based on the year and the relics carving style, it was from the Ancient Bali period (11th century). Then there is a $154 \mathrm{~cm}$ tall standing woman figure made from hardened soil. At the back, it is written Bhatari Mandul, year 999 Saka (1077 AD), with Kadiri Kuadarat letter. A standing male statue with its right hand stretched down parallel to the body while the left hand bent forward. The researchers from Udayana University, estimated it to be made during the Middle Bali period ( 13 th century). ${ }^{9}$

In addition to statues that represent leaders at that time, there are also deities' figures, such as Brahma, with four-faces, or known as Catur Muka, carrying lotus buds. It has the meaning of spiritual awakening. According to its rigid style carving, the figure is estimated to be made in the Middle Bali era (13th century), same as the Bhatari Mandul statue. Moreover, a statue of Ganesha with the characteristics of elephant-headed, the human body with a distended belly, four arms, and has one ivory. Behind its head carved with decorative leaves. The statue was also considered from the Middle Bali period (13th century). The old remnants described how the society in ancient civilization developed, from the prehistoric period until Hinduism influence spread on the island. Since many precious artifacts are being kept in the temple, thus every night, locals at Sukawana village guard the temple in the shift.

The oldest inscription about Bali is dated from eighth century. It is believed, Bali Mula people inhabited Bali since $250 \mathrm{BC}$, based on the age of bones and sarcophagus found on the island. ${ }^{10}$ the first migration came from Java in, led by Rsi Markandeya. He and 4000 People of Aga came to Bali. Later the people are known as Bali Aga people. Then, the second wave was an exodus from Java after the Majapahit kingdom fell. After Majapahit invasion to Bali, there was dozens of improvement on how Hinduism being practiced on the island. ${ }^{11}$ However, the community who lived in several areas was left untouched, including 
sukawana village. Therefore, their ritual is unique, unlike the other regions in Bali. One of example is when the ceremony is taking place at Puncak Penulisan temple; the ritual is led by a priest called Jero Kubayan whereas another area that received Majapahit influence, the ritual is led by a priest called Pandita or Sulinggih. There are two Kubayan, namely Kubayan Kiwa and Kubayan Mucuk. Both were in charge of leading the prayer during the ceremony. Jero Kubayan has ritual equipment in the form of machetes which he uses as tools during the ceremony procession. The mantra he recites while performing worship is called Puja sana.

The social structure in Sukawana village is known as ulu apad. Kubayan is the highest social position, responsible for the village and ritual ceremony at Puncak Penulisan temple. The position is chosen by the community and can only be replaced when the person in charge has great-grandchildren. However, if the Kubayan does not have offspring, the title will be held until death. In social activities, Kubayan does not receive any special treatment from the community, except during the pamadegan ceremony or the inauguration ceremony for Kubayan, the residents of Sukawana village take full responsibility. Under the position of Kubayan, there is a position called krama panglanan, Naka, nyingguk, and kabau.

The other interesting fact about Puncak Penulisan temple and its community is a unique ritual that can only be found here, called the ritual 'Pengurip Jagad Bali Kabeh.' The ceremony is held every 700 years in this ancient temple, by sacrificing 12 buffaloes (Ngebo roras). Then, every ten years, the grand renewal ceremony is held called 'Ngebo papat.' The holy relic of Pucak Panulisan's deity that is being kept in Bale Agung Sukawana temple would be carried to Puncak penulisan Temple. On the ceremony, the communities would sacrifice four buffaloes and a deer. Furthermore, every full moon on the fourth month in Balinese calendar, a deer and buffalo would be sacrificed.

In every ceremony that takes place in the temple, is taking care by a group of people called Gebog domas. Gebog Domas consists of 200 family heads from Sukawana, Kintamani, Selulung, and Bantang regions, bringing a total of 800 people. The community of Sukawana Village acts as the group in charge. Should in the ceremony experiencing lack of facilities, then the sukawana would fulfill their duty. The existence of Gebog Domas was fundamental in the local community organization since it was believed that Gebog Domas played an essential role as a symbol of unity between villages as well as to strengthen the brotherhood. ${ }^{13}$

\section{CONCLUSION}

Puncak Penulisan temple is a temple complex, in a site resembles a seven level terraces pyramid. In ancient Balinese Kingdom period, between $882-1436 \mathrm{AD}$, the community sanctified several temples, including Puncak Penulisan temple as a place to worship the spirit of ancestor as well as their ruler. Discovered artifacts from this ancient site encompass varies type of megalithic artifacts such as a stone carved with moon and sun image, a statue of Brahma, three pairs statues, two Lingga-Yoni as a symbol of Lord Shiva, Ganesha figure, and several mini rock shrine to worship the holy spirit. unlike other regions in Bali, in Puncak Penulisan temple, the ritual is led by a priest called Jero Kubayan. Furthermore, in every ceremony that takes place in the temple, is taking care by a group of people called Gebog domas. A group of people consists of 200 family heads from Sukawana, Kintamani, Selulung, and Bantang regions, bringing a total of 800 people. Gebog Domas played an essential role as a symbol of unity between villages as well as to strengthen the brotherhood.

\section{REFERENCES:}

1. Image taken from Senna Bali Tour. Puncak Penulisan Temple as Bali Temple Tourism Object. Available at URL: https://www.sennabalitour.com/bali-tourism/ bali-cultural-tourism/bali-cultural-temple-tourism/balitourism-object/bali-puncak-penulisan-cultural-templetourism

2. Anonymous. Telusuri Jejak Pura Puncak Penulisan Bali, Pura Tertua di Pulau Dewata. Kintamani[dot]id. Accessed on 26 February 2018. Available at URL: https://www. kintamani.id/telusuri-jejak-pura-puncak-penulisan-balipura-tertua-pulau-dewata-001068.html

3. Gede I, Raharja M. Kajian Konsep Ruang Punden Berundak Pura Penulisan Pada Kaldera Gunung Batur Purba. 2018.

4. Anonymous. Pura Puncak Penulisan Bali. Situsbudaya[dot] id. Accessed on 17 January 2019. Available at URL: https:// situsbudaya.id/pura-puncak-penulisan-bali/

5. Anonymous. Pura puncak penulisan tempat ibadah dari masa Bali Age. Indonesia[dot]travel. Accessed on 17 January 2019. Available at URL: https://www.indonesia. travel/id/destination/359/batur/article/175/pura-puncakpenulisan-tempat-ibadah-dari-masa-bali-age

6. Transcript of 'Prasasti Sukawana'. Available at URL: https:// dokumen.tips/download/link/prasasti-sukawana

7. Utami LS. ASPEK KEMASYARAKATAN DI BALIK MAKANAN DALAM PRASASTI BALI KUNA. InForum Arkeologi 2018 Jun 29 (Vol. 25, No. 2, pp. 107-116).

8. Image collection of PGW Sayoga. Telusuri Jejak Pura Puncak Penulisan Bali, Pura Tertua di Pulau Dewata. Kintamani[dot]id. Available at URL: https://www. kintamani.id/telusuri-jejak-pura-puncak-penulisan-balipura-tertua-pulau-dewata-001068.html

9. Stutterheim WF. Indian influences in Old-Balinese art. The India Society; 1935.

10. Soejono RP. Sistim-sistim penguburan pada akhir masa prasejarah di Bali (Doctoral dissertation, FIB-UI). 1977 
11. David J. Stuart-Fox. Pura Besakih: Pura, Agama dan Masyarakat Bali. Udayana University Press. 2010. ISBN 978-979-3790-36-7.

12. Image taken from Balipuspanews[dot]com. KBS Ikuti Upacara "Mepepada" di Pura Puncak Penulisan. 2017. Available at URL: https://www.balipuspanews.com/kbsikuti-upacara-mepepada-di-pura-puncak-penulisan.html
13. Srinayani NP, Suastika IN, Sudiatmaka K, Si M. EKSISTENSI GEBOG DOMAS SEBAGAI INTEGRASI KRAMA (Studi kasus di kota Bangli, Kec, Bangli, Kab, Bangli). Jurnal Pendidikan Kewarganegaraan Undiksha. 2014 Jul 21;2(1).

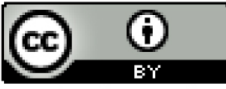

This work is licensed under a Creative Commons Attribution 